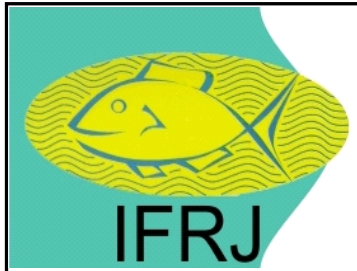

Available online at: http://ejournal-balitbang.kkp.go.id/index.php/ifrj

e-mail:ifrj.puslitbangkan@gmail.com

INDONESIANFISHERIES RESEARCHJOURNAL

Volume 25 Nomor 1 June 2019

p-ISSN: 0853-8980

e-ISSN: 2502-6569

Accreditation Number RISTEKDIKTI: 21/E/KPT/2018

\title{
CHARACTERISTIC OF SMALL SCALE TUNA FISHERIES ASSOCIATED WITH FADS IN LABUHAN LOMBOK, WEST NUSA TENGGARA-INDONESIA
}

\author{
Fathur Rochman ${ }^{\star 1}$, Irwan Jatmiko' and Zulkarnaen Fahmi ${ }^{1}$ \\ ${ }^{1}$ Research Institute for Tuna Fisheries, Jl. Mertasari, No. 140, Sidakarya, Denpasar, Bali-Indonesian \\ Received; May 31-2017 Received in revised from May 07-2019; Accepted May 23-2019
}

\begin{abstract}
Fish aggregating devices, or FADs are used extensively in developing countries to attract and to collect pelagic fish and give positive impacts on fish production. Use of FADs has started in early $20^{\text {th }}$ century with different names among the countries and regions. This study investigated the design, deployment, distribution, density and the number of FADs used by small scale tuna fisherman in Labuhan Lombok, including characteristics of fishing boat, fishing gear, catch composition, catch per unit of effort (CPUE), fish diversity and species richness. There were 65 FADs identified in this study and 47 of them were in normal distribution. Type of the FADs used was anchored FADs, spreading between 56.63 to 267.70 NM from Labuhan Lombok fishing port. The placement of FADs were arranged in such a way as to resemble a fence, in which the distance from one to another was close. It is expected to disrupt tuna movement towards the strait in the small islands around West Nusa Tenggara. The dimensional size of vessels used to catch fish was small boat $(<7 \mathrm{GT})$ with handline as fishing gears. Fish catches were dominated by skipjack $(40.30 \%)$ followed by yellowfin tuna $(30.90 \%)$, tuna juvenile $(13.44 \%)$, frigate tuna $(4.19 \%)$, albacore $(3.41 \%)$, bigeye tuna $(2.71 \%)$ and others $(5.03 \%)$. The highest nominal CPUE occurred in January and February, accounted for $278 \mathrm{~kg}$ and $285 \mathrm{~kg}$ per day at sea respectively. The average diversity of fish and species richness in FADs area were 1.07674 and 1.3573 correspondingly. Overall results inform that diversity of fish, productivity and ecosystem were at sufficient condition and mid ecological pressure but species richness was in low condition. If this continues, it is possible that tuna diversity will decrease and endanger the survival of tuna species and others species related to the tuna.
\end{abstract}

Keywords: FADs; tuna fisheries; Indian Ocean; Labuhan Lombok; West Nusa Tenggara

\section{INTRODUCTION}

Fish aggregating devices (FADs) are used intensively in developing countries (Albert et al., 2014) to attract and to collect pelagic fish and give a positive impact on production in small scale, industrial scale and recreational scale of pelagic fisheries in the world (Castro et al., 2002: Caddy \& Majkowsky, 1996; Morales-Nin et al., 2000; Buckley et al., 1989; Fonteneau et al., 2000). In tuna fisheries, FADs is used over $40 \%$ of world tropical tuna and has a great expansion over the past three decades.

The use of FADs in developing countries have started in early $20^{\text {th }}$ century, formed as traditional raft anchored in coastal zone and exploited a small pelagic fish (Anderson \& Gates, 1996). In some countries, FADs have a specific name i.e rumpon (Indonesia), unjang (Malaysia) and payaos (Philipine). Rumpon has been traditionally used in Indonesia, especially in Eastern Indonesian waters since immemorial time (Monintja, 1976; Nasution et al., 1986). According to (Nasution et al., 1986), the traditional fishermen in Mamuju South Sulawesi have used the rumpon for a long time although there is no record when the first time rumpon used. There are several names of rumpon in Indonesia i.e tendak (West Java), uncang (Sumatera) and romping (Sulawesi). According to (Mathews \& Monintja, 1996), the intensive study on deep sea FADs for tuna and skipjack fisheries in Indonesia was begun in 1976 and commercial operation was successful in 1985. FADs are able to affect the catchability and abundance of yellowfin and skipjack tuna. They may also make the fish stock more susceptible to overfishing. The construction of rumpon was different among the regions in Indonesia. According to (Rosa et al., 2015). The fishermen in Java sea construct their rumpon from coconut leaves and bamboo stems in order to catch small pelagic fishes but the fishermen in Sulawesi construct their 
rumpon using bamboo rafts with rattan mooring line to cacth tuna and tuna like species.

Currently, FADs have grown rapidly not only the traditional one but also the industrial scale which is a large size, has a permanent or drifting anchored FADs, deployed in deep water, set up outside the coastal area and equipped with tracking devices (Fonteneau et al., 2000). In Indian Ocean, the FADs grow very rapidly at the beginning of tuna purse seine fleet in 1984. It was estimated that there are 10.000 of drifting FADs deployed by industrial purse seine in Indian Ocean (Fonteneau et al., 2000). An anchored FADs are also used by artisanal fleets in Indian Ocean (Tessier et al., 2000), especially for small scale and recreational scale fisheries.

There are several studies focused on FADs system i.e the effectiveness (D'anna et al., 1999), function (Castro et al., 2002) of FADs, species composition, temporal trend (Andaloro et al., 2003) and feeding habit (Deudero, 2001; Sinopoli et al., 2004) of fish species correlated with FADs. Further studies suggested that FADs might be disrupted migration patterns of some migratory species (Marsac et al., 2000; Taquet et al., 2000) and modification of feeding regime for some species with poor condition of growth and survival rates (Taquet et al., 2000). Labuhan Lombok is one of the major fishing ports of small scale FADs based tuna fisheries in Indonesia and Indian Ocean. Labuhan Lombok located in West Nusa Tenggara -Indonesia. In 2012, there were 1.461 boats consisting of troll line boats $614(42 \%)$, hand line boats 775 (53\%) and net boats (gill net and mini purse seine) 72 (5\%) (RITF, 2014).

The aims of this study is to investigate the design, deployment, distribution, density and the number of FADs which were used by small scale tuna fisheries in Labuhan Lombok. Moreover, this study also investigated type of fishing boats, fishing gears, catch composition, catch per unit of effort (CPUE), fish diversity and species richness of FADs-based small scale tuna fisheries in Labuhan Lombok. This study also gave the information to government for FAD and tuna resource managements in Indian Ocean.

\section{MATERIALS AND METHODS Data Collection}

The information on FADs designs, type of fishing boats and type of fishing gears were obtained from interview and direct measurement in Labuhan Lombok fishing port in the period 26 February - 04 March 2014 , 15 - 21 June 2014 and 15-25 October 2014 respectively. The respondents were the handline fishermen who landed the catch in Labuhan Lombok fishing port where the selection of respondents was done randomly. Nine samples of fishing boats, gears and FADs design were measured.

The information of FADs deployment, distribution, density and the number of FADs were obtained from fisherman's logbook enumeration program and onboard observer program in 2016. The information on catch per unit of effort (CPUE), catch composition, fish diversity index and species richness index from enumeration and observer program of the Research Institute for Tuna Fisheries (RITF) in 2016.

\section{Data Analysis}

The distribution of FAD data was normalized using Kolmogorov-Smirnov and Shapiro-Wilk tests where P value must be $>=0.05$. The normal data distribution was acquired by removing all of data sets that had high deviation in box plot, normal Q-Q plot and detruded normal $Q-Q$ plot so that obtained $P$ value $>=0.05$ in Kolmogorov-Smirnov and Shapiro-Wilk test. SPSS software was used to normalize the data.

CPUE was determined as the number of catches (weight) per unit effort (the number of days at sea), in which a ship landed fish catches in Labuhan Lombok Fishing Port.

Fisheries diversity index ( $\left.H^{\prime}\right)$ describes the diversity, productivity, pressures on ecosystems and stability of the fisheries ecosystem in FADs. Fisheries diversity data was obtained from onboard observer program conducted from August $26^{\text {th }}$ to September $07^{\text {th }} 2016$ using two motor boats, i.e. KM Versace 13 and KM Permata Merah, and fishing at 13 FAD points. Fisheries diversity index was calculated using Shannon-Wiener (Krebs, 1978a, b) with the following formula:

$$
H^{\prime}=-\sum_{i=1}^{s}(P i)(\log P i)
$$

Where:

$H^{\prime}=$ Fish diversity of Shannon-Wiener index

$\mathrm{S}=$ the number of species

$\mathrm{Pi}=$ the proportion of the amount of an individual species-i with the total individual number

Restu (2000) divided biodiversity index into three criteria as described in Table 1.

Fisheries richness in FADs can be determined by species richness Margalef (Santosa, 1995) with the following formula: 


$$
R=\frac{s-1}{\operatorname{Ln}(N O)}
$$

Where:

$\mathrm{R}=$ Species Richness Index
$\mathrm{S}=$ Total number of species in the habitat

NO $=$ Total number of individual in the habitat

According to (Magurran, 1988), fisheries richness index benchmark consists of three criteria as mentioned in Table 2.

Table 1. Fish Biodiversity Shannon- Wiener Index (Restu, 2000).

\begin{tabular}{ll}
\hline \multicolumn{1}{c}{ Biodiversity Index } & \multicolumn{1}{c}{ Option } \\
\hline $\mathrm{H}^{\prime}<1.0$ & $\begin{array}{l}\text { Fish biodiversity is low, poor, low productivity as indication of } \\
\text { heavy pressure and unstable ecosystem. }\end{array}$ \\
$1.0<\mathrm{H}^{\prime}<3.322$ & $\begin{array}{l}\text { Fish biodiversity, productivity and ecosystem were in sufficient } \\
\text { condition and mid ecological pressure. }\end{array}$ \\
$\mathrm{H}^{\prime}>3.322$ & $\begin{array}{l}\text { Fish biodiversity, productivity and ecosystem were in high } \\
\text { condition and resistant to ecological pressure }\end{array}$ \\
\hline
\end{tabular}

Table 2. Species richness Margalef (Magurran, 1988)

\begin{tabular}{ll}
\multicolumn{1}{c}{ Richness Index } & \multicolumn{1}{c}{ Option } \\
\hline $\mathrm{R}<3.5$ & Spesies richness is in low condition \\
$3.5 \leq \mathrm{R}<5$ & Spesies richness is in mid condition \\
$\mathrm{R}>5$ & Spesies richness is in high condition \\
\hline
\end{tabular}

\section{RESULT AND DISCUSSION}

Result

\section{FADs Design, deployment and distribution}

FADs was used by fisherman based in Labuhan Lombok as fishing tool to attract free schooling fish, especially tuna and tuna like species. The FADs type used in Labuhan Lombok was anchored FADs (Figure 1), with the construction consisting of buoy, bamboo rafts, attractors and ballasts. Buoy was made of cork (Styrofoam) and secondhand tires with $3 \mathrm{~m}$ length, 1 $\mathrm{m}$ width and $1 \mathrm{~m}$ height. Sometimes buoy made from foam that was filled in steel cylinders with rounded nose cone. Bamboo rafts were made of bamboo series with $15 \mathrm{~m}$ length and attached to swivel connecting to the fish attractor. The main function of bamboo rafts was to put the light as additional attractor to attract positive photo taxis pelagic fish. The swivel was made from two secondhand tires which were strung together with tether and attractor (palm leaves). Attractor was tied to a buoy with a rope in which arranged below swivel and spliced with polyethylene (PE) with diameter $14 \mathrm{~mm}$. FADs rope was adjustable with depth of water and estimated to reach up to $\pm 3.000 \mathrm{~m}$ depth.

There were 65 FADs that have been identified in Indian Ocean along West Nusa Tenggara waters (Figure 2) and 47 of those in normal distribution. The closest distance from Labuhan Lombok fishing port was $56.63 \mathrm{NM}$ and the farthest distance was 263.70 NM. From the normal distribution of FADs, the closest distance between FADs ranged from 1.91 to 10.11 NM with the average distance was $5.86 \mathrm{NM}$. Distribution of FAD distance less than $5 \mathrm{NM}, 5$ to 10 NM and more than $10 \mathrm{NM}$ from Labuhan Lombok fishing port was $31.91 \%, 63.83 \%$ and $4.26 \%$ respectively (Figure 3 ). 


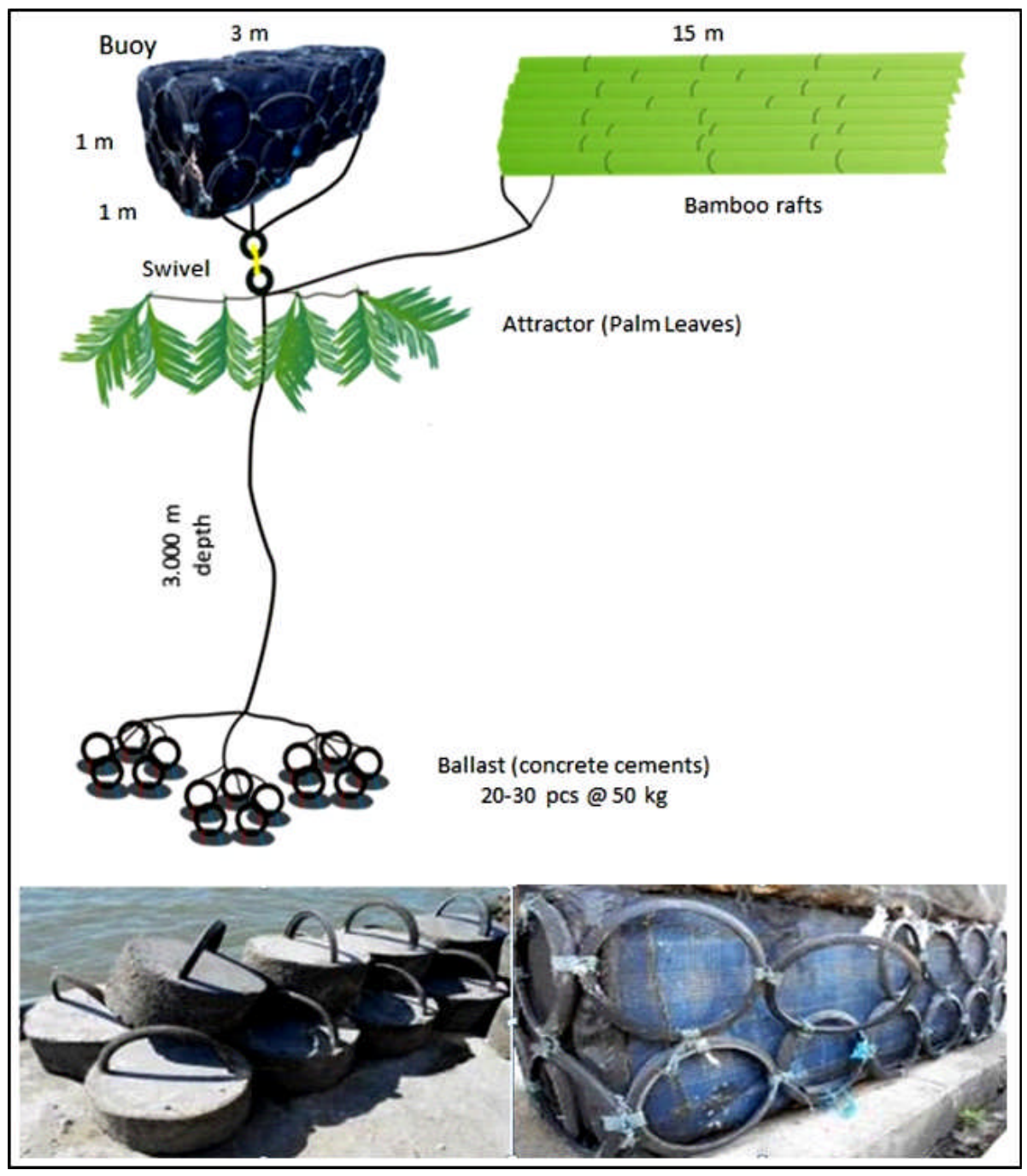

Figure 1. FADs design of small scale fisheries in Labuhan Lombok, West Nusa Tenggara.

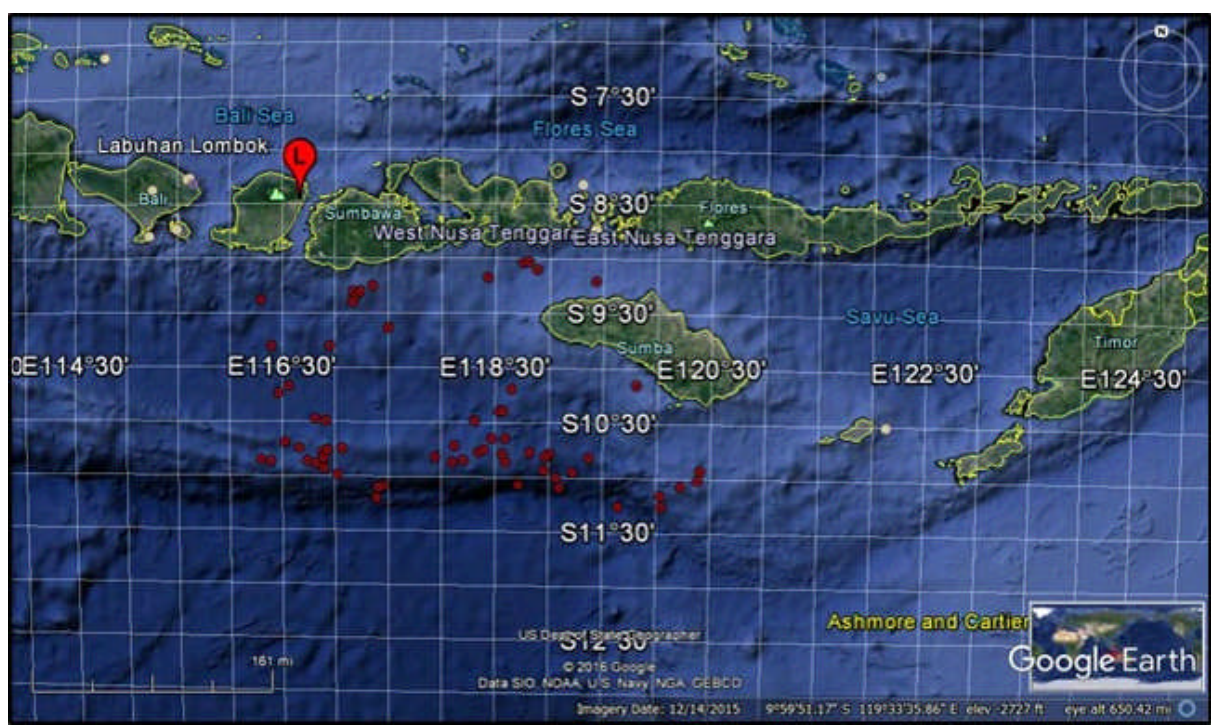

Figure 2. FADs distribution of Labuhan Lombok handline small scale tuna fisheries in Indian Ocean, the information collected from enumeration and onboard observation in Labuhan Lombok (2014-2016). 


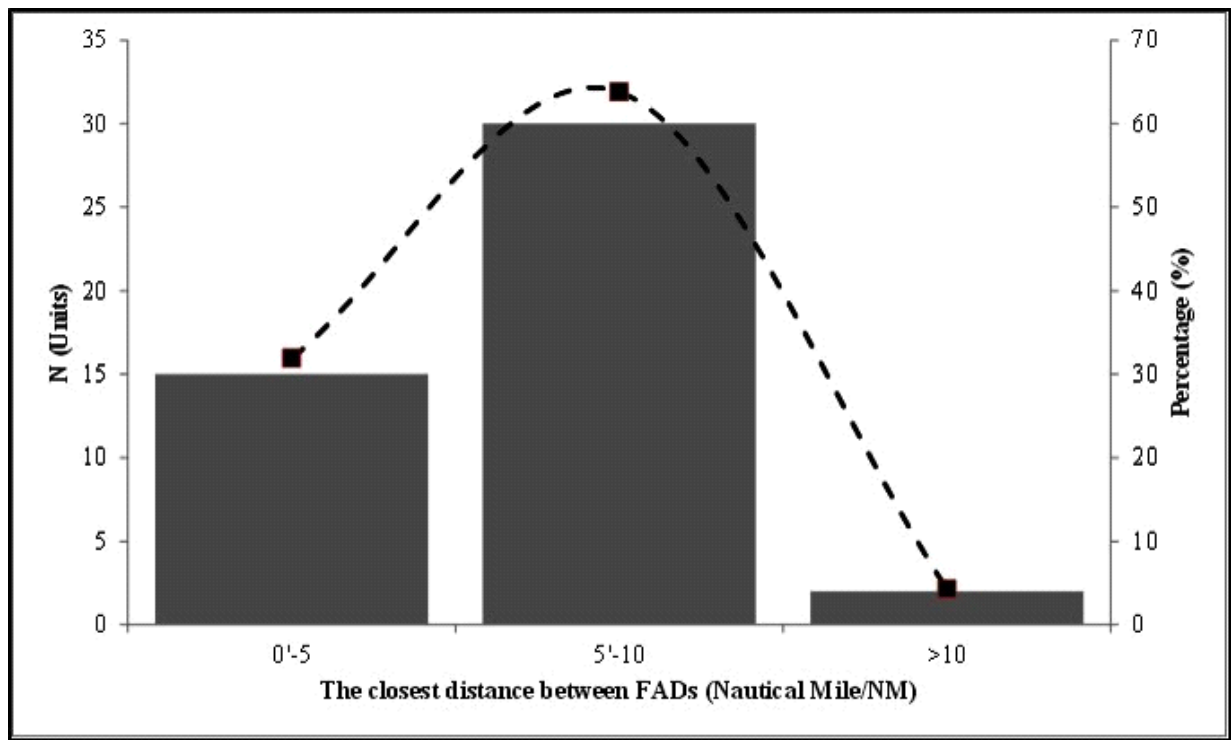

Figure 3. The closest distance between FADs of Labuhan Lombok Handline tuna fisheries in Indian Ocean.

\section{Fishing Boat and Catch Composition}

Actually the boats used by Labuhan Lombok fisherman was handline small boat (sekoci) with gross tonnage under 7 GT. Those boats constructed by wooden base with dimension length $13-17 \mathrm{~m}$, width $3-3,5 \mathrm{~m}$, and depth $1-1,5 \mathrm{~m}$. These boats equipped with three fish boxes of 1.5 ton capacity, double engine $30 \mathrm{HP}, 5$ crews and trip duration 10-12 days at sea (Figure 4).

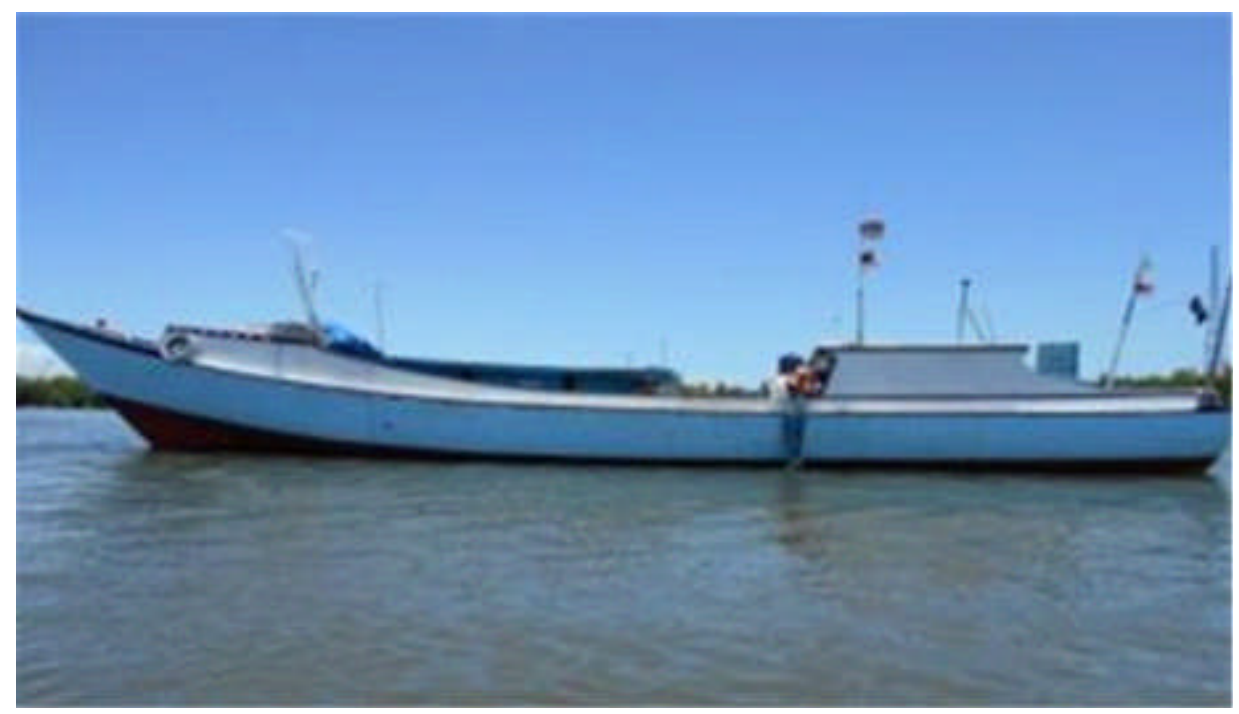

Figure 4. Handline boat based in Labuhan Lombok fishing port.

The catch composition of handline tuna fisheries associated with FADs was dominated by skipjack $(40.30 \%)$ followed by yellowfin tuna $(30.90 \%)$, tuna juvenile $(13.44 \%)$, frigate tuna $(4.19 \%)$, albacore $(3.41 \%)$, bigeye tuna $(2.71 \%)$ and others $(5.03 \%)$ (Figure 5).

\section{Production, Effort and CPUE}

The increasing of production should not be in line with the increasing of effort and CPUE. Sometimes the production was inversely proportional to effort and CPUE. In 2016, the highest production and effort were occurred in April and May respectively but the highest nominal CPUE was obtained in January and February. The highest production reaching up to 224 to 268 ton per month in April and May with the highest effort were 1,604 to 1,753 days at sea per month correspondingly. The highest nominal CPUE occurred in January and February was 278 to $285 \mathrm{~kg}$ per day at sea respectively (Figure 6). 


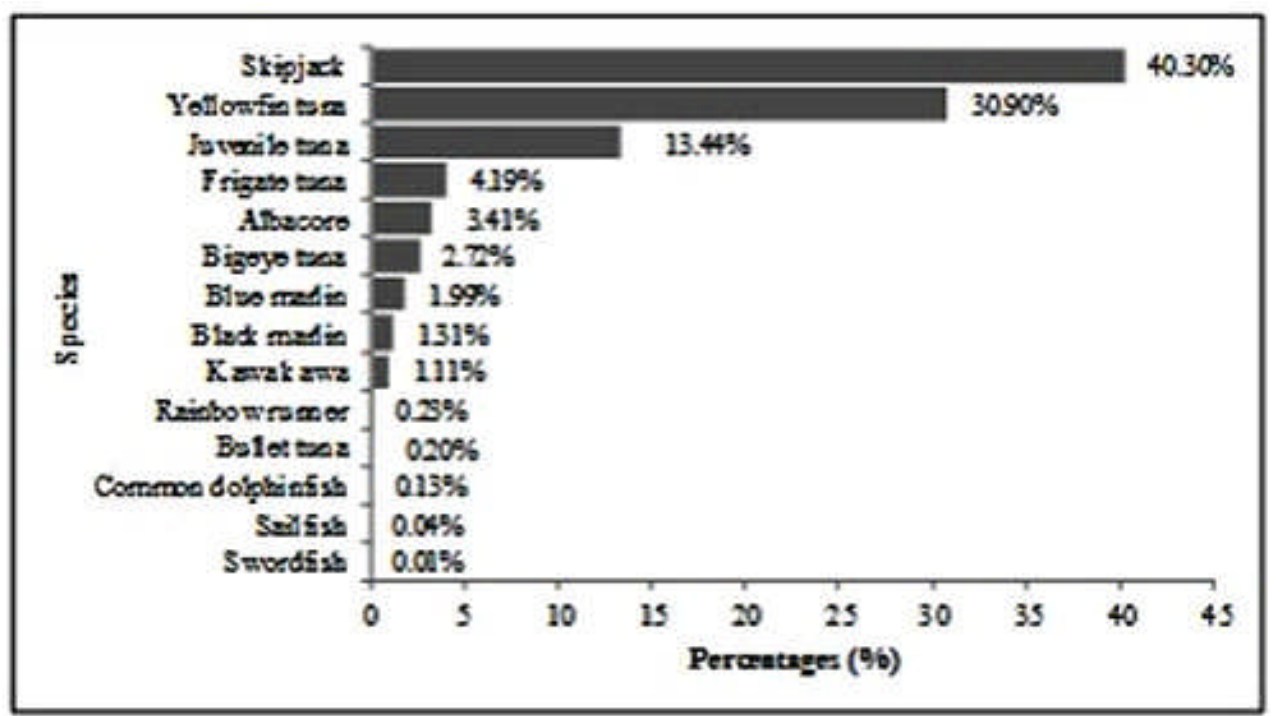

Figure 5. Catch composition of Labuhan Lombok handline smale scale tuna fisheries in Indian Ocean, the information obtained from enumeration program 2014-2016 and observer program 2016.

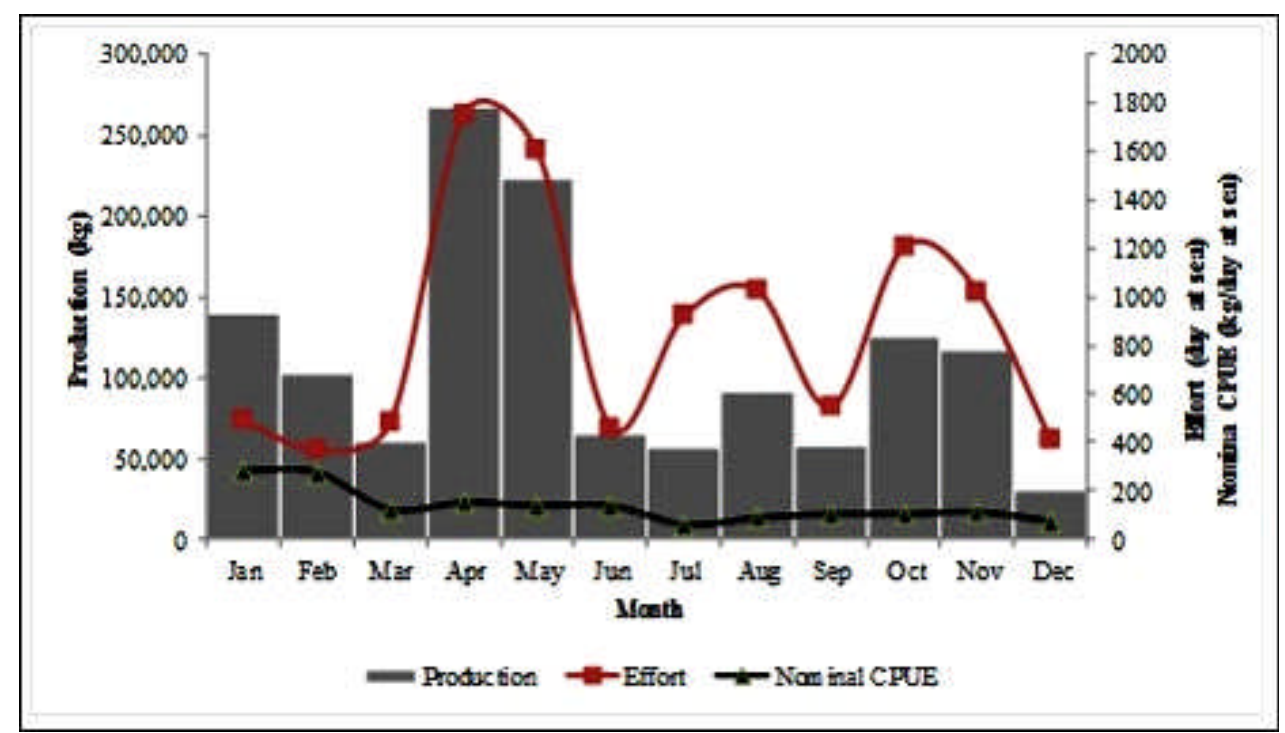

Figure 6. Production, effort and CPUE of FADs-handline small scale tuna fisheries in Labuhan Lombok, the data was collected from enumeration program 2016.

\section{Diversity and Richness Indexs}

There were 11 species caught by handline small scale tuna fisheries along around the FADs in Indian Ocean. Those kinds of species were skipjack, yellowfin tuna, bigeye tuna, common dolphinfish, and others (Appendix 1). Diversity ( $\left.H^{\prime}\right)$ and species richness $(R)$ were 1.07674 and 1.3573 respectively. Fish catches was dominated by skipjack with domination index $\left(\mathrm{Pi}^{2}\right) 0.3762$ and density 29.9 species $/ \mathrm{km}^{2}$ followed by yellowfin tuna $\left(\mathrm{Pi}^{2} 0.06708\right.$; density 12.6 species $\left./ \mathrm{km}^{2}\right)$, bigeye tuna $\left(\mathrm{Pi}^{2} 0.005186\right.$; density 3.5 species $\left./ \mathrm{km}^{2}\right)$, common dolphinfish $\left(\mathrm{Pi}^{2}\right.$ 0.000919 ; density 1.5 species $/ \mathrm{km}^{2}$ ) and others (Appendix 1).

\section{Discussion}

Actually, the FAD used by Labuhan Lombok handline tuna fishery was industrial FAD type where FADs construction required a very high cost. The manufacturing cost of FADs in Labuhan Lombok was up to $\$ 5.000$ per unit so manufacturing cost must be shared by several fisherman. One unit of FAD was commonly used by some fisherman in rotation and alternately.

FADs design was similar to those purse seine FADs in Philippine and Papua New Guinea where the FADs used foam in steel cylindrical float, coconut fronds, inlayed polypropylene rope and plastic 
strapping that suspended beneath the anchored FAD float. These anchored FAD was seldom marked with radar reflector or navigation aids (Prado, 1991; Anderson \& Gates, 1996; Itano, 2007).

The average space between FAD of Labuhan Lombok small scale fisheries was 5.86 NM where $95.74 \%$ of which were under $10 \mathrm{NM}$. Besides that, the installation of FAD could cause fence effect (zigzag). Low density of FAD (less than $10 \mathrm{NM}$ ) will disrupt fish movement from off shore to in shore and will form a fence preventing fish migration to neritic area and straits in Bali and Lombok Island. The preliminary study showed that deployment and distribution of FAD (floating object) along Indian Ocean can bring about disturbances of fish migratory pattern such as dolphinfish Coryphaena hippurus (Marsac et al., 2000) and tuna species (Taquet et al., 200). FAD can also lead the ecological trap of tuna species in the open ocean (Taquet et al., 2000) and modify feeding regime of some species (Brock, 1985; Buckley \& Miller, 1994) with unfavorable performance in growth rate and survival rate of Coryphaena hippurus and tuna-tuna like species (Taquet et al., 2000). The Indonesian Government through Ministry of Marine and Fisheries Affairs (MMFA) has issued MMFA decree no 26/2014 regarding with FAD management. This regulation adjust all aspects regarding $F A D$ distribution i.e:

1. The proposed FAD must be suitable with proposed fishing area.

2. The FAD must not interfere cruise line

3. The FAD should not be installed in sea channel.

4. The distance between FAD should not be less than $10 \mathrm{NM}$

5. The FAD should be installed with no fence effect (zigzag)

According to this MMFA regulation, the FAD distribution and deployment of Labuhan Lombok small scale fisheries were not in line with the regulation and had many contradictions.

Tropical tuna species dominated the catch by $87.36 \%$, followed by neritic tuna $5.3 \%$, temperate tuna $3.41 \%$ and others $3.93 \%$. From the tropical tuna species, skipjack was dominated the catch $40 \%$, followed by yellowfin tuna $30.90 \%$ and juvenile tuna (yellowfin tuna and bigeye tuna) 13.44\%. The high catch of juvenile tuna ( $>10 \%$ of the total catch) was one of the characteristics of tuna fisheries associated with FAD. This fact is very interesting to discuss because according to IOTC (2016) yellowfin tuna species was declared to be overfished and subjected to overfishing. The stock status significantly changed in 2015 as a direct consequence of the large and unsustainable fishing of yellowfin tuna occurring over the last three years and demonstrating a low recruitment level. The indication of low recruitment level shown by $13.44 \%$ of catch of Labuhan Lombok small scale tuna fisheries was juvenile tuna. This fact will reduce the opportunity of juvenile tuna to develop and to add a new recruitment in Indian Ocean stock.

Production volume $(\mathrm{kg})$ and effort (the number of days at sea) normally have a positive correlation where the increase of effort will be followed by the increase of production volume. Nevertheless, the increase of production volume and effort levels were not necessarily accompanied by the increase of catch per unit of effort (CPUE). The highest production volume and effort were obtained in April and May but the highest CPUE level obtained in January and February respectively. This phenomena occurs because there was usually MJO (Madden-Jullian Oscillation) phase in December until February (30-60 days) (Madden \& Julian, 1972), in which there is a large scale of tropical variability propagating around the world that is approximately happened in 30-60 day time scale. MJO will generate a big change known as the impact of tropical cyclone (TC) activity such as vertical wind shear, vertical motion, relative vorticity and low/mid-level moisture (Madden \& Julian, 1972; Zhang, 2012; Moncrieff et al., 2012). The combination of MJO effect may lead to extreme weather events such as high tropical cyclone with wave height over 4 $\mathrm{m}$. MJO phase can cause the fishermen reluctant to go fishing even though the tuna catch is very high. According to (Taufikurrahman \& Hidayat, 2017), there is an upwelling phenomenon in fishing ground of the south coast of Lombok and Sumbawa Island during December, January and February which are marked by positive values of Ekmant transport with average $0.34 \times 10-6 \mathrm{~m} 2 \mathrm{~s}-1$. This occurrence results in a period, in which water being rich in nutrients moves to the surface. This phenomenon leads to increased primary productivity followed by increased secondary productivity and Fish diversity of tuna fisheries assocated with FAD is in good condition where the fish biodiversity, productivity and ecosystem indices are in sufficient condition and at moderate ecological pressure but still slightly above the threshold. However, the richness indexes in lower condition $(<3.5$ of Margalef Indexs). If this continues, it is possible that tuna diversity will decrease and endanger the survival of tuna species and others species related to the tuna.

\section{CONCLUSION}

FAD is the main fishing tool used by tuna handline fishermen based in Labuhan Lombok fishing port. FAD 
distribution and deployment were in Indian Ocean waters south off West Nusa Tenggara-Indonesia. The average space between FAD was in low density which will affect the aquatic ecosystems in the oceans in term of fish biodiversity and richness indexs. These facts recommend to introduce a better management to adjust the installation of FADs and law enforcement in the implementation of FAD regulation in accordance with MMFA decree no 26/2014 in order to guarantee sustainability of fishery resources, especially in tuna fisheries.

\section{ACKNOWLEDGEMENT}

I would like to thank to Ministry of Marine and Fisheries Affairs, The Agency of Research and Human Resource of Marine and Fisheries, Fisheries Research and Development Centre, and Research Institute for Tuna Fisheries for financial support. I also would like to thanks to observers of Research Institute for Tuna Fisheries (RITF) Bali and the head of RITF for valuable inputs and comments.

\section{REFERENCE}

Albert, J. A., Beare, D., Schwarz, A. M., Albert, S., \& Warren, R., (2014). The contribution of nearshore fish aggregating devices (FADs) to food security and livelihoods in Solomon Islands. PLOS ONE 9(12): e115386. doi: 10.1371/ journal.pone.0115386.

Andaloro, F., Campo, D., Sinopoli, M., Castriota, L., \& Campagnuolo, S. (2003). Pelagic fish community associated with FADs in the Sicilian coast (Southern Tyrrhenian Sea). In: Proceedings of the fish symposium on ecosystems and molecular approach 5-9 March 2001. Universidade da Madeira,Centro de Ciensas Biologicas e Geologicas, Funchal (Portugal) pp. 78-83.

Anderson, J., \& Gates, P. D. (1996). South Pacific commission fish aggregating Device (FAD) Manual Vol. 1 CSouth Pacific Commission. 46.

Brock, R. E. (1985). Preliminary study of the feeding habits of pelagic fish around Hawaiian Fish Aggregating Devices, or can fish aggregation devices enhance local fish productivity? Bull. Mar. Sci., 37, 40-49 pp.

Buckley, R.M., Itano, D.G., \& Buckley, T.W. (1989). Fish aggregation device (FAD) enhancement of shore fisheries in American Samoa. Bull Mar Sci, 44(2), 942-949.
Buckley, T. W., \& Bruce, S. M. (1994). Feeding habits of yellowfin tuna associates with fish aggregation device in American Samoa. Bulletin of Marine Science, 55 (2-3), 445-459.

Caddy, J.F., \& Majkowski, J. (1996) Tuna and trees: a reflection on a long-term perspective for tuna fishing around floating logs. Fish Res, 25, 369-376.

Castro, J. J., Santiago, J.A., \& Santana-Ortega, A.T. (2002). A general theory on fish aggregation to floating objects: An alternative to the meeting point hypothesis. Reviews in Fish Biology and Fisheries 11: 255-277 pp.

D’Anna, G., Badalamenti, F., \& Riggio, S. (1999a) Traditional and experimental floating fish aggregating devices in the Gulf of Castellammare (NW Sicily): results from catches and visual observations. Sci Mar, 63(3-4), 209-218.

Deudero, S. (2001). Interspecific trophic relationships among pelagic fish species underneath FADs. $J$ Fish Biol, 58, 53-67.

Fonteneau, A., Pallares, P., Pianet, R. (2000) Worldwide review of purse-seine fisheries on FADs. In: Le Gall J-Y, Cayré P, Taquet M (eds) Pêche thonière et dispositifs de concentration de poissons, (ed) Ifremer, Actes Colloq, 28, 15-35.

IOTC (2016). Report of the 18th Session of the IOTC working party on tropical tunas. Seychelles, 5-10 November 2016. IOTC-2016-WPTT18-R[E].

Itano, D. (2007). An examination of FAD-related gear and fishing strategies useful for data collection and FAD-based management. WCPFC Scientific Committee, third regular session, Aug. 13-24, 2007, Honolulu.

Krebs, C.J. (1978a). Ecological methodology. New York: Harper and Row Publisher.

Krebs, C.J. (1978b) Ecology: the experimental analysis of distribution and abudance. New York: Harper and Row Publishers.

Madden, R. A., \& Julian, P. R. (1972): Description of global-scale circulation cells in the tropics with a 40-50 day period. J. Atmos. Sci, 29, 1109-1123.

Magurran, A.E. (1988). Ecological diversity and its measurement. London: Croom Helm. [A general book on ecological diversity. Models (for the distribution of species)]. 
Marsac, F., Fonteneau, A., \& Menard, F. (2000) Drifting FADs used in tuna fisheries: an ecological trap? In: Le Gall J-Y, Cayre P, Taquet M (eds) Pêche Thonière et Disposifs de concentration de poison. (Ed) Ifremer, Actes Colloq, 28, 537-552.

Mathews, C. P., \& Monintja, D. R. (1996). Assessment of the role of foreign and industrial tuna fishing in Indonesia's IEEZ, archipelagic and territorial waters. Report Central Research Institute for Fisheries Research, Jakarta.

Moncrieff, M. W., D. E. Waliser, M. J. Miller, M. E. Shapiro, G. Asrar, and J. Caughey, (2012). Multiscale convective organization and the YOTC Virtual Global Field Campaign. Bull. Amer. Meteor. Soc., 93, 1171-1187 pp.

Monintja, D. R. (1976). Modernizing the traditional rumpon to increase fishermen's income in Indonesia. Documented papers proposed to Indonesian Directorate General of Capture Fisheries, Jakarta. 6p.

Morales-Nin, B., Cannizzaro, L., Massutí, E., Potoschi, A., Andaloro, F. (2000). An overview of the FADs fishery in the Mediterranean Sea. In: Le Gall J-Y, Cayré P, Taquet $M$ (eds) Pêche thonière et dispositifs de concentration de poissons. (Ed) Ifremer, Actes Colloq, 28,184-207.

Nasution, C. H., Merta, G. S., \& Arifudin, R. (1986). Study on romping and their aspect in Mamuju water to develop tuna fisheries in South Celebes. Journal of Marine Fisheries Research, 37, 31-58.

Prado, J. (1991). Some considerations on surface and midwater FADs technology and utilization. In: Papers Presented at the Symposium on Artificial Reefs and Fish Aggregating Devices as Tools for the Management and Enhancement of Marine Fishery Resources, Colombo, Sri Lanka, 14-17 May 1991. RAPA Report 1991/11. RAP A, FAO, Bangkok, Thailand. 264-278.

Restu, I.W. (2002). The study of the development of Mangrove tourism in Ngurah Rai forest park in south coastal region of Bali (in Indonesia). [Thesis]. Bogor: Post Graduate Program, Bogor Agricultural Institute.

RITF. (2014). Annual report of small scale tuna fisheries research in Indian Ocean south off Java and Nusa Tenggara 2014. Research Institute for Tuna Fisheries, The Agency of Research \& Development, Ministry of Marine \& Fisheries AffairIndonesia. 169 p.

Rosa, Y., Mulyono, S. B., \& Daniel, M. (2015). Impact of fish aggregating device on sustainable capture fisheries. The $1^{\text {st }}$ International Symposium on Aquatic Product Processing 2013. ISSN 24130877 (2015). 224-237.

Santosa, Y. (1995). Training on measurement techniques and biodiversity monitoring in Indonesian tropical forests (in Indonesia). Department of Forest Resources Conservation. Faculty of Forestry, Bogor Agricultural Institute. Bogor.

Sinopoli, M., Pipitone, C., Campagnuolo, S., Campo, D., Castriota, L., Mostarda, E., \& Andaloro, F. (2004) Diet of young-of-the-year bluefin tuna, Thunnus thynnus (Linnaeus, 1758) in the southern Tyrrhenian (Mediterranean sea). J Appl Ichthyol, 20, 310-313.

Taquet, M., Reynal, L., \& Laurans, M. (2000). Do FADs influence the geographical distribution of dolphinfish (Coryphena hippurus)? In: Le Gall J-Y, Cayre P, Taquet $M$ (eds) Pêche Thonière et Disposifs de concentration de poison, (ed) Ifremer, Actes Colloq. $28,528-536$.

Taufikurrahman, Q., \& Hidayat, R. (2017). Coastal upwelling in souther coast of Sumbawa island, Indonesia. IOP Conf. Series: Earth and Environmental Science 54 (2017) 012075 doi:10.1088/1755-1315/54/1/012075

Tessier, E., Rey-Valette, H., Ah-Nieme, D., Bargain, R.M., Venkatasamy, A., \& Wendling, B., (2000). Halieutic systems and FADs in the Indian ocean: a review of the various trials carried out and the results obtained in terms of integration and overall benefits. Ifremer, Actes Colloq. 28. 159-183 pp.

Zhang, C. (2012). Vertical structure from recent observations. Intraseasonal Variability of the Atmosphere-Ocean Climate System, 2nd ed. W. K.-M. Lau and D. E. Waliser, Eds., Springer, 537548. 


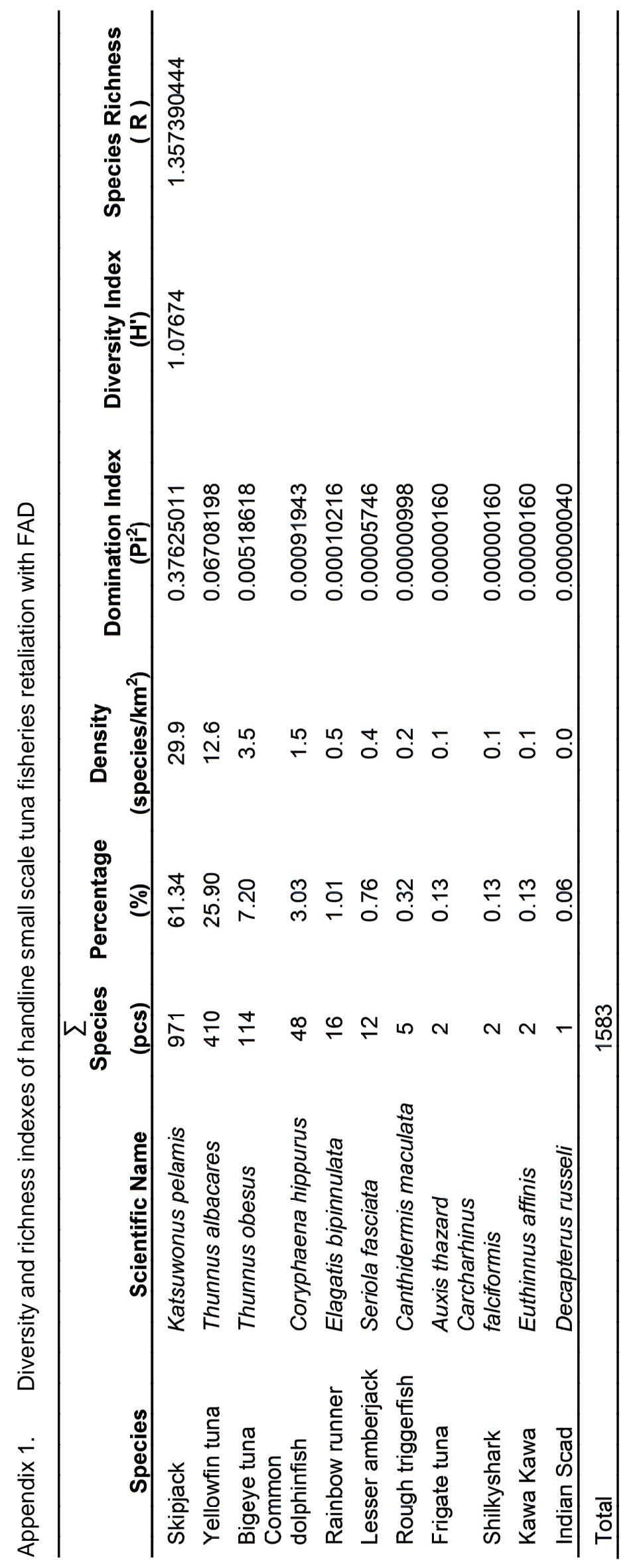

